\title{
PENINGKATAN HASIL BELAJAR MATEMATIKA MELALUI IMPLEMENTASI METODE PEMBELAJARAN COOPERATIVE LEARNING TIPE COOPERATIVE INTEGRATED READING AND COMPOSITION (CIRC) PADA SISWA SMA NEGERI 1 PUNGGUR
}

\author{
Noto Margianto \\ SMA Negeri 1 Punggur \\ Email: notomargianto10@gmail.com
}

\begin{abstract}
This study aims to improve student learning outcomes through the implementation of cooperative learning method of CIRC type. This type of research is Classroom Action Research. The subject of the recipients of the action is the students of grade XII IPA 4 Senior High School 1 Punggur, amounting to 33 students. Data collection methods used are observation method, test method, documentation method and field note. Data analysis technique used are data analysis process, data presentation, and data verification. To guarantee the validity of data used triangulation technique. The result of the research shows the improvement of mathematics learning outcomes of students on Logarithmic subject. This can be seen from: 1) Student's completeness before the action is 14 students $(39,13 \%)$ and at the end of action reaches 19 students $(82,61 \%), 2)$ The courage of student to ask unclear material before action that is 5 Students (21.74\%) and at the end of the action reached 15 students (65.22\%), 3) Students who responses to other students' opinions before action is 2 students (8.69\%) and at the end of the action reaches 11 students $(47,82 \%), 4)$ Enthusiastic students to do the problem before the action that is 8 students $(34,78 \%)$ and at the end of action reaches 17 students $(73,91 \%)$. The conclusion of this research is the implementation of cooperative learning method type CIRC can improve student learning achievement of mathematics on Logarithmic subject.
\end{abstract}

Keywords: CIRC, cooperative learning, learning outcomes

\section{PENDAHULUAN}

Pendidikan merupakan suatu kebutuhan yang mendasar bagi kemajuan suatu bangsa. Pendidikan bersifat mutlak dan tidak dapat dipisahkan dari kehidupan masyarakat. Salah satu masalah pendidikan yang dihadapi bangsa Indonesia adalah rendahnya mutu pendidikan bagi setiap jenjang dan satuan pendidikan. Upaya peningkatan kualitas pendidikan merupakan salah satu fokus di dalam pembangunan Indonesia. Untuk mencapai kemajuan harus ada upaya yang sungguhsungguh baik dari lembaga resmi pemerintah atau masyarakat pada umumnya. Sekolah sebagai lembaga pendidikan formal yang mendapat prioritas utama untuk menyelenggarakan proses belajar mengajar, mempunyai tugas dan tanggung jawab yang besar. Pada kenyataannya, dalam melaksanakan kegiatan belajar mengajar yang dapat mencapai tujuan yang telah ditetapkan bukanlah suatu hal yang mudah. Oleh karena itu diperlukan suatu strategi belajar mengajar yang paling efektif dan efisien.

Keberhasilan suatu proses belajar mengajar dipengaruhi oleh 
beberapa faktor. Namun, keberhasilan tersebut lebih banyak dipengaruhi oleh metode pembelajaran yang digunakan guru, karena metode pembelajaran merupakan suatu cara yang digunakan dalam penyampaian materi pelajaran. Jadi metode pembelajaran inilah yang akan memberikan arahan jalannya proses belajar mengajar, sehingga akan sangat menentukan keberhasilan dalam mencapai tujuan pembelajaran yang dimaksud. Berdasarkan penggunaan metode yang tepat diharapkan siswa tidak akan mengalami kesulitan untuk memahami konsep dan akhirnya bisa menggunakan ilmu yang siswa terima sebagai peran aktif dimasa mendatang.

Pembelajaran matematika yang berlangsung saat ini mayoritas guru masih menggunakan metode pembelajaran konvensional yang jarang sekali mengajak siswanya untuk mengembangkan kemampuan dirinya dalam kehidupan sehari- hari. Akibat dari pembelajaran seperti ini siswa mengalami kesulitan dalam menangkap konsep matematika yang diajarkan oleh guru, karena didalam kegiatan belajar mengajar pengetahuan diberikan begitu saja tanpa dikaitkan dengan pengalamanpengalaman siswa sebelumnya. Konteks dimana siswa berada pada saat proses pembelajaran berlangsung. Mengajar hanya merupakan transfer pengetahuan dari guru ke murid. Dengan pembelajaran matematika yang seperti ini, siswa akan belajar matematika hanya dengan cara menghafal dan sekedar mengingat rumus. Padahal matematika lebih bersifat abstrak, sehingga dengan pembelajaran dengan menghafal dan mengingat sesuatu yang abstrak, menjadikan matematika akan terkesan lebih sulit dan membosankan serta menjadikan prestasi belajar matematika siswa pada umumnya rendah.

Untuk mengantisipasi masalah tersebut agar tidak berkelanjutan, maka guru berusaha menyusun dan menerapkan metode pembelajaran. Salah satu metode pembelajatan yang akan diterapkan adalah metode pembelajaran cooperative learning tipe Cooperative Integrated Reading and Composition (CIRC). Metode pembelajaran cooperative learning tipe CIRC atau disebut juga kooperatif terpadu, membaca dan menulis termasuk salah satu tipe metode pembelajaran cooperative learning. Menurut Jenisa dan Lubis (2016: 78) Pembelajaran kooperatif tipe CIRC dari segi bahasa dapat diartikan sebagai suatu model pembelajaran kooperatif yang mengintegrasikan suatu bacaan secara menyeluruh kemudian mengkomposisikannya menjadi bagianbagian yang penting. Menurut Slavin (2011: 200) pada awalnya model CIRC diterapkan dalam pelajaran bahasa. Dalam kelompok kecil para siswa diberi suatu teks/bacaan, kemudian siswa latihan membaca atau saling membaca, memahami ide pokok saling merevisi dan menulis ikhtisar atau memberikan tanggapan. Menurut Slavin (2011:204) CIRC memiliki beberapa unsur utama,yaitu sebagai berikut: kelompok atau tim, pemberian wacana, kegiatan-kegiatan yang berhubungan dengan wacana, (membaca berpasangan, mengidentifikasi masalah, menemukan kata kunci) pemeriksaan pasangan, pengajaran langsung dalam memahami wacana, dan tes. Menurut Neni, dkk. (2012: 157) penerapan pembelajaran kooperatif model CIRC dapat dijadikan sebagai alternatif pembelajaran matematika di kelas agar siswa tidak merasa bosan dengan pembelajaran 
yang biasa dilakukan. Pembelajaran ini merupakan salah satu pembelajaran yang mampu meningkatkan hasil belajar siswa, karena siswa mampu bekerja sama dengan baik bersama anggota kelompoknya. Adapun langkah-langkahnya sebagai berikut:

1) Membentuk kelompok beranggotakan 4 orang yang heterogen.

2) Guru member wacana sesuai dengan topik.

3) Siswa bekerja sama saling membacakan dan menemukan ide pokok dan memberi tanggapan terhadap wacana ditulis pada kertas.

4) Mempresentasikan hasil

5) Guru membuat kesimpulan

6) Penutup.

Berdasarkan karakteristik yang dimiliki oleh masing-masing model pembelajaran tersebut, maka model pembelajaran yang akan digunakan dalam penelitian ini adalah model CIRC model ini menekankan pada kerjasama antara siswa untuk menemukan ide pokok dan saling memberi tanggapan terhadap topik yang sedang dipelajari. Cooperative learning tipe $\mathrm{CIRC}$ ini lebih menonjolkan interaksi dalam kelompok, dengan demikian siswa dapat menerima siswa lain yang berkemampuan dan berlatar belakang berbeda. Dengan demikian siswa tidak hanya menerima saja materi pengajaran yang diberikan guru, melainkan siswa dilatih untuk menggali dan mengembangkan materi dalam kelompok belajarnya. Kompetisi antar kelompok belajar akan menumbuhkan motivasi belajar pada siswa yang berpengaruh terhadap hasil belajar akan berkembang dan hasil belajar siswa akan lebih baik.

Penelitian ini secara umum bertujuan untuk mendiskripsikan proses pembelajaran yang dilakukan oleh guru matematika melalui metode pembelajaran cooperative learning tipe CIRC untuk meningkatkan hasil belajar matematika siswa. Secara khusus untuk mengetahui peningkatan hasil belajar siswa dalam pembelajaran matematika pada materi logaritma setealah dilakukan proses pembelajaran dengan menerapkan metode cooperative learning tipe CIRC.

\section{METODE PENELITIAN}

Pada penelitian ini merupakan Penelitian Kualitatif dengan desain Penelitian Tindakan Kelas (PTK) yaitu penelitian yang mengkombinasikan prosedur penelitian dengan tindakan subtantif, suatu tindakan yang dilakukan dalam disiplin inquari, atau suatu usaha seseorang untuk memahami apa yang sedang terjadi, sambil terlibat dalam sebuah proses perbaikan dan perubahan. Menurut Hopkins (Sutama, 2011: 15). Penelitian ini dilakukan pada siswa kelas XII SMA Negeri 1 Punggur tahun ajaran 2015/2016 yang berjumlah 33 siswa. Penelitian dilaksanakan secara bertahap. Adapun tahapan pelaksanaan penelitian adalah sebagai berikut:

a) Tahap Persiapan dilaksanakan pada bulan April - Mei 2015.

b) Tahap Pelaksanaan dilaksanakan pada bulan Agustus 2015.

c) Tahap Pengumpulan data dilaksanakan pada bulan Oktober 2015.

d) Laporan dilaksanakan pada bulan November 2015

Penelitian tindakan kelas bercirikan adanya perbaikan terus menerus terhadap proses pembelajaran dimana dari perbaikan tersebut akan meningkatkan kualitas pembelajaran dikelas.

Penelitian tindakan merupakan kegiatan pemecahan masalah yang 
dimulai dari: 1) dialog awal; 2) Perencanaan tindakan; 3) Pelaksanaan; 4) Pengamatan; 5) Refleksi; 6) Penyimpulan data.

Dalam pengumpulan data-data yang dibutuhkan, peneliti melakukan beberapa kegiatan dengan menggunakan teknik pengumpulan data, yaitu : (1) Tes dilakukan setelah materi selesai diberikan berguna untuk mengetahui tingkat kemampuan siswa dalam memahami materiyang diajarkan, (2) observasi digunakan untuk mengamati siswa dan guru secara langsung dalam interaksi pelajaran matematika, (3) dokumentasi digunakan untuk memperoleh data sekolah SMA Negeri 1 Punggur dan identitas siswa antara lain nama siswa dan nomor induk siswa, serta foto rekaman proses tindakan penelitian, (4) catatan lapangan digunakan sebagai pertimbangan dalam pelaksanaan putaran selanjutnya untuk menimalkan permasalahan dari putaran sebelumnya.

Penerapan metode pembelajaran cooperative learning tipe CIRC ini diaplikasikan pada materi logaritma pada siswa kelas XII SMA Negeri 1 Punggur dengan melibatkan guru mata pelajaran matematika kelas XII. Pada penelitian tindakan kelas ini, data dianalisis sejak tindakan pembelajaran dilakukan dan dikembangkan sejak refleksi sampai proses penyusunan laporan. Menurut Sutama (2010:100-101) analisis data dalam penelitian ini dilakukan menggunakan metode alur yaitu meliputi : (1) Proses analisis data, merupakan proses menyeleksi data dari beberapa sumber kemudian menentukan fokus, meringkas, menyusun, dan mengubah bentuk data yang ada ke dalam catatan lapangan. (2) Penyajian data, penyajian data dilakukan dalam rangka pemahaman terhadap sekumpulan informasi yang memberi kemungkinan adanya penarikan kesimpulan. (3) Verifikasi data, verifikasi data ini dilakukan secara bertahap untuk memperoleh derajat kepercayaan yang tinggi. Dengan demikian langkah analisis data dalam penelitian tindakan ini dilakukan sejak tindakan dilakukan.

Analisis hasil pada penelitian ini ditekankan hasil belajar siswa. Hasil belajar ini dapat dilihat dari ketuntasan siswa yang mencapai KKM dengan nilai lebih dari sama dengan 75 , keaktifan bertanya kepada guru tentang materi yang belum jelas, keberanian menanggapi pendapat siswa lain, dan antusias siswa mengerjakan soal yang diberikan dari guru.

\section{HASIL PENELITIAN DAN PEMBAHASAN}

Hasil kerja kolaborasi yaitu hasil pelaksanaan tindakan kelas yang dilaksanakan oleh guru matematika kelas XII SMA Negeri 1 Punggur bersama peneliti dengan menerapkan metode pembelajaran cooperative learning tipe CIRC dapat meningkatkan hasil belajar siswa dalam proses pembelajaran matematika. Peningkatan hasil belajar siswa terlihat saat proses pembelajaran, hal ini terbukti dari adanya peningkatan siswa yang mencapai batas tuntas dengan KKM nilai lebih dari sama dengan 75 , keaktifan bertanya kepada guru tentang materi yang belum jelas, keberanian siswa menanggapi pendapat siswa lain dan antusias siswa mengerjakan soal yang diberikan dari guru.

Data yang diperoleh mengenai hasil belajar siswa sebelum dilakukan tindakan sampai putaran III secara keseluruhan ditunjukkan pada 
ISSN 2089-8703 (Print) Vol. 6, No. 1 (2017)

ISSN 2442-5419 (Online)

Tabel 1 sebagai berikut:

Tabel 1. Data Peningkatan Hasil Belajar Matematika Siswa Kelas XII SMA Negeri 1 Punggur

\begin{tabular}{|l|l|c|c|c|c|}
\hline No & \multicolumn{1}{|c|}{ Aspek } & $\begin{array}{c}\text { Sebelum } \\
\text { Tindakan }\end{array}$ & Putaran I & Putaran II & Putaran III \\
\hline 1. & Siswa yang mencapai KKM & $39,13 \%$ & $56,62 \%$ & $73,91 \%$ & $82,61 \%$ \\
\hline 2. & $\begin{array}{l}\text { Menanyakan materi yang } \\
\text { belum jelas }\end{array}$ & $21,74 \%$ & $43,48 \%$ & $52,17 \%$ & $65,22 \%$ \\
\hline 3. & $\begin{array}{l}\text { Menanggapi pendapat siswa } \\
\text { Lain }\end{array}$ & $8,69 \%$ & $17,39 \%$ & $30,43 \%$ & $47,82 \%$ \\
\hline 4. & Antusias mengerjakan soal & $34,78 \%$ & $47,83 \%$ & $56,53 \%$ & $73,91 \%$ \\
\hline
\end{tabular}

Hasil belajar yang dimaksud dalam penelitian ini yaitu pertama, ketuntasan belajar siswa. Ketuntasan belajar siswa ini dimaksudkan jika siswa sudah mencapai Kriteria Ketuntasan Minimal (KKM) dengan nilai lebih dari sama dengan 75 maka siswa dikatakan tuntas dan sudah mencapai hasil belajar yang baik. Siswa dikatakan tuntas belajar dalam setiap putaran jika mencapai KKM dengan nilai $\geq 75$ dari seluruh soal yang diberikan. Nilai siswa yang belum mencapai KKM akan remidial dan yang sudah mencapai KKM diberikan pengayaan. Kedua, adalah keaktifan bertanya dimana siswa aktif dalam bertanya tentang materi yang belum dipahami kepada guru ini dimaksudkan jika keaktifan bertanya siswa meningkat atau jumlah siswa yang bertanya meningkat maka bisa dikatakan hasil belajar meningkat. Ketiga, adalah keberanian siswa dalam menanggapi pendapat siswa lain, ini dimaksudkan jika siswa semakin berani saling menanggapi pendapat antar siswa lain maka bisa dikatakan hasil belajar meningkat. Keempat adalah antusias mengerjakan soal dari guru, ini dimaksudkan jika siswa semakin antusias dan aktif mengerjakan soal dari guru maka hasil belajar matematika siswapun bisa meningkat.
Pembahasan berisi tentang uraian dan penjelasan mengenai hasil tindakan kelas. Pada pembehasan ini akan membahas penelitian yang telah dilakukan oleh peneliti dan peneliti terdahulu. Pembahasan antar putaran mengenai peningkatan hasil belajar siswa yaitu membandingkan apakah terjadi peningkatan dari sebelum tindakan kelas sampai tindakan kelas Putaran III. Penerapan metode pembelajaran cooperative learning tipe CIRC dapat meningkatkan hasil belajar siswa kelas XII SMA 1 Punggur pada pelajaran matematika. Hal ini dapat dilihat dari meningkatnya ketuntasan belajar siswa dengan KKM nilai lebih dari sama dengan 75 , keaktifan bertanya kepada guru tentang materi yang kurang jelas, keberanian menenggapi pendapat siswa lain dan antusias mengerjakan soal dari guru. Sebagai dampak pembelajaran yang aktif dan menyenangkan tersebut, sehingga hasil belajar siswa juga mengalami peningkatan.

Peningkatan hasil belajar siswa pada setiap putaran juga dapat dilihat dari; 1) Ketuntasan belajar siswa sebelum adanya tindakan sebanyak 9 siswa $(39,13 \%)$ dan di akhir tindakan mencapai 19 siswa $(82,61 \%), 2)$ Keberanian siswa menanyakan materi yang belum jelas sebelum tindakan 
yaitu sebanyak 5 siswa $(21,74 \%)$ dan di akhir tindakan mencapai 15 siswa $(65,22 \%), 3)$ Siswa yang menanggapi pendapat siswa lain sebelum tindakan yaitu sebanyak 2 siswa $(8,69 \%)$ dan di akhir tindakan mencapai 11 siswa $(47,82 \%)$, 4) Antusias siswa mengerjakan soal sebelum tindakan yaitu sebanyak 8 siswa $(34,78 \%)$ dan di akhir tindakan mencapai 17 siswa $(73,91 \%)$. Kesimpulan penelitian ini adalah dengan implementasi metode pembelajaran cooperative learning tipe Cooperative Integrated Reading and Composition (CIRC) dapat meningkatkan hasil belajar matematika siswa pada pokok bahasan Logaritma.

Hasil penelitian ini relevan dengan penelitian yang telah dilakukan oleh Wijayanti (2007) terhadap siswa di SMA Negeri 1 Punggur menyatakan, bahwa terdapat peningkatan kemampuan komunikasi matematika yang signifikan pada siswa yang memperoleh

pembelajaran matematika melalui implementasi metode pembelajaran cooperative learning tipe CIRC. Penelitian lain yang dilakukan oleh Purwanti (2007), yang dilaksanakan di Kelas XII SMA Negeri 1 Punggur, bahwa kemampuan peran aktif dalam pembelajaran matematika, siswa yang mendapat pembelajaran dengan moetode pembelajaran cooperative learning tipe CIRC lebih baik daripada siswa yang mendapat pembelajaran dengan pendekatan tradisional ditinjau secara keseluruhan walaupun belum mencapai taraf yang optimal, yaitu baru mencapai taraf cukup. Hal ini juga didukung dalam penelitian Jenisa dan Lubis (2016) Penerapan model pembelajaran Cooperative Integrated Reading and Composition (CIRC) dapat meningkatkan hasil belajar konstruksi bangunan pada Siswa
Kelas X Program Keahlian Teknik Gambar Bangunan SMK Negeri 1 Lubuk Pakam.

\section{KESIMPULAN DAN SARAN}

Hasil penelitian tindakan kelas yang dilakukan secara kolaboratif antara peneliti dengan guru matenatika kelas XII SMA Negeri 1 Punggur dalam pembelajaran matematika melalui penerapan metode pembelajaran cooperative learning tipe CIRC untuk meningkatkan hasil belajar matematika, dapat diambil beberapa kesimpulan. Adapun beberapa kesimpulan yang dapat diambil berdasarkan tindakan kelas yang telah dilakukan adalah adanya peningkatan hasil belajar pada siswa melalui penerapan metode pembelajaran cooperative learning tipe CIRC, hal tersebut dapat dilihat dari; 1) Ketuntasan belajar siswa sebelum adanya tindakan sebanyak 9 siswa $(39,13 \%)$ dan di akhir tindakan mencapai 19 siswa $(82,61 \%)$, 2) Keberanian siswa menanyakan materi yang belum jelas sebelum tindakan yaitu sebanyak 5 siswa $(21,74 \%)$ dan di akhir tindakan mencapai 15 siswa $(65,22 \%), 3)$ Siswa yang menanggapi pendapat siswa lain sebelum tindakan yaitu sebanyak 2 siswa $(8,69 \%)$ dan di akhir tindakan mencapai 11 siswa $(47,82 \%)$, 4) Antusias siswa mengerjakan soal sebelum tindakan yaitu sebanyak 8 siswa $(34,78 \%)$ dan di akhir tindakan mencapai 17 siswa $(73,91 \%)$. Kesimpulan penelitian ini adalah dengan implementasi metode pembelajaran cooperative learning tipe Cooperative Integrated Reading and Composition (CIRC) dapat meningkatkan hasil belajar matematika siswa pada pokok bahasan Logaritma.

Kesimpulan tersebut memberikan implikasi bahwa 
penerapan metode pemberlajaran cooperative learning tipe CIRC merupakan salah satu alternatif untuk meningkatkan hasil belajar matematika pada materi logaritma. Metode pembelajaran cooperative learning tipe CIRC juga memlikik peranan yang berarti dalam meningkatkan motivasi siswa dalam pembelajaran matematika yang meliputi keaktifan siswa dalam bertanya pada guru, keberanian menanggapi pekerjaaan siswa lain dan antusias siswa dalam mengerjakan soal. Dengan menerapkan metode pembelajaran ini dapat membangun sendiri pengetahuan siswa, terjalin hubungan yang lebih dekat antara siswa dengan siswa lain sehingga siswa akan berpartisipasi dalam pembelajaran sehingga hasil belajar matematika siswa meningkat. Dengan perbaikan cara mengajar melalui metode pembelajaran cooperative learning tipe CIRC guru tidak lagi mendominasi dalam proses pembelajaran karena siswa juga ikut berpartisipasi aktif dalam pembelajaran sehingga guru hanya bertindak sebagi fasilitator dan motivator.

Berdasarkan hasil penelitian ini, peneliti memberi saran kepada; (1) guru matematika perlu menumbuh kembangkan motivasi dan semangat siswa dalam mengerjakan soal serta memberikan pengertian kepada siswa bahwa jika soal dikerjakan secara serius dan sungguh-sungguh hasilnya akan baik sehingga hasil belajar matematika siswa dapat meningkat dan guru matematika perlu mengembangkan keaktifan dan rasa berani siswa dalam bertanya dan mengemukakan ide yaitu dengan guru memusatkan kegiatan pembelajaran kepada siswa serta guru tidak mendominasi kegiatan pembelajaran dan hanya bersikap sebagai fasilitator pada waktu proses belajar mengajar berlangsung, (2) siswa hendaknya fokus dan memahami dalam proses pembelajaran dan hendaknya para siswa menghilangkan opini yang berkembang dimasyarakat bahwa matematika adalah pelajaran yang sulit dan menakutkan sehingga diharapkan dapat belajar matematika dengan senang agar materi pelajaran dapat lebih mudah dipahami, (3) peneliti selanjutnya diharapkan peneliti dapat melakukan penelitian yang serupa dengan penelitian ini tetapi menggunakan pendekatan atau metode yang berbeda.

\section{DAFTAR PUSTAKA}

Jenisa, K. dan Lubis, A. 2016. Penerapan Model Pembelajaran Cooperative Integrated Reading And Composition (CIRC) Untuk Meningkatkan Motivasi Dan Hasil Belajar Konstruksi Bangunan Siswa Kelas X TGB SMK Negeri 1 Lubuk Pakam. Jurnal Education Buuilding. Vol. 2, No. 1, h: 77-86

Neni. dkk. 2012. Penerapan Model Pembelajaran Kooperatif Tipe CIRC (Cooperative Integrated Reading And Composition) Dalam Meningkatkan Hasil Belajar Siswa Pokok Bahasan Aritmatika Sosial Siswa Kelas VIIC SMPN 5 Jember Semester Ganjil Tahun Ajaran 2012/2013. Kadikma, Vol. 3, No. 3, hal 147158.

Purwanti, H. 2005. Upaya

Meningkatkan Peran Aktif

Siswa dalam Pembelajaran Matematika melalui Model Pembelajaran Kooperatif Tipe CIRC di Kelas VIII SMP Negeri 2 Depok Yogyakarta.Yogyakarta: Skripsi Jurusan Pendidikan 
ISSN 2089-8703 (Print) Vol. 6, No. 1 (2017)

ISSN 2442-5419 (Online)

Matematika FMIPA UNY.

Slavin, R. E. 2011.Cooperative Learning Teori, Riset dan Praktik. Bandung: Nusa Media.

Sutama. 2010. Penelitian Tindakan teori dan praktek dalam PTK, PTS, dan PTBK. Semarang: CV Citra Mandiri Utama.

Wijayanti, N. 2007. Implementasi Model Pembelajaran CIRC Untuk Meningkatkan Prestasi Belajar Matematika Siswa Di SMAN 1 PUNGGUR: Skripsi FKIP 